\title{
University Characteristics as Factor Affecting the Creation of University Spin-Offs
}

\author{
Jan Hunady \\ Faculty of Economics, Matej Bel University in Banska Bystrica, Slovakia \\ Marta Orviska \\ Faculty of Economics, Matej Bel University in Banska Bystrica, Slovakia \\ Peter Pisar \\ Faculty of Economics, Matej Bel University in Banska Bystrica, Slovakia
}

\section{Abstract}

The university-spin off company is a specific but rather effective tool for the direct transfer of knowledge and new technology from academia into business. However, this seems to be still a not very common phenomenon in many European countries. The paper aims to compare the characteristics of universities in European countries based on empirical data for 2465 higher education institutions in Europe retrieved from European Tertiary Education Register database. We examined factors that could have a potential effect on the creation of university spin-off companies in Europe. In order to find these factors we applied logit and probit regression analysis. Our results strongly suggest that those universities which are neither strongly focused on a few fields of research, nor very broad in their focus are mostly less active in creating the university spin-off companies. The intensity of PhD study, the share of tuition fees as well as a number of foreign students seem to be factors affecting university spin-off activities.

Keywords: Universities, Spin-off, Research, Tertiary education, Knowledge transfer JEL classification: O33, 123, M13

Acknowledgments: This contribution was supported by the Slovak Research and Development Agency (APVV), APVV-14-0512 "Universities and regional development".

\section{Introduction}

Universities have been for centuries considered a key element in the creation and accumulation of knowledge in society. There two main tasks are primarily to create a highly skilled labour force for the labour market and to generate new knowledge through science and research. These two functions should be interlinked to the extent that universities are in essence performing a third function, which is the effective transfer of knowledge gained from research into economic practice. This function is also a very important one especially in terms of the successful accumulation of human capital and securing the technological progress of the economy. Establishment of university spin-off companies is one way of getting knowledge and technologies from a university environment into the practice. Even though it seems to be an effective way of transferring knowledge, its use is still very limited in many European countries, either by valid legislation or by the lack of experience of universities. Even though a spin-off is usually considered to be the 
founding of a new company to commercialize the results of university research, it could also be an enterprise founded by university employees or graduates.

The main objective of our research is to identify the key characteristics of universities influencing the probability of establishing a university spin-off company. In the next chapter we will briefly explain the theoretical background for the transfer of technology and knowledge into economic practice through the establishment of university spin-off companies. In the next sections, we compare selected indicators for university characteristics in several European countries and we will further examine the potential factors affecting the establishment of university spin-offs. Universities are supposed to be one of the driving forces of innovation processes in the country. As stated by Dunning (2002), innovative processes are the main engine of economic development in general. In general we can say that innovation consists of knowledge that arises as a result of scientific, research and development activities and, consequently, the ability of workers to apply them into practice (Hudec et al., 2009). With respect to that, there are several studies that came to the conclusion that the intensity of science, research and development together with the proportion of tertiary educated people are the key factors supporting innovation performance and thus also economic development (Sterlacchini, 2008).

The universities and research institution are part of so called innovation system. Freeman (1987) defines innovative systems as a network of institutions in the public and private sectors whose activities and interactions are aimed at supporting, importing and diffusing new technologies. According to Edquist (2004), the innovation system has a major role to play in the development, dissemination and exploitation of innovation.

The traditional role of universities in innovation system lies primarily in activities within the education and research subsystem. Thus, universities provide businesses with new knowledge gained in research and development, which are then transformed into innovation.

Another potential way how the role of universities in the innovation system could be described is through the triple helix model. The triple helix model captures the potential relationships between universities, industry and government. The quality of connections between these three subjects is a very important factor for developing innovation and further technological development of the economy (Etzkowitz et al., 2000). Of course there are also other theoretical concepts, seeing universities as part of external environment affecting the innovation processes in business. Hence, in general we can say that universities could be either seen as important part of innovation process or as external sources of information for innovation process (Chesbrough, 2006). However, the new knowledge, which is often developed at universities, is still often not transferred into the business to a substantial extent. There is always a certain sort information barrier between research organizations or universities and business. In order to support this transfer, there needs to be institutions at the national and regional levels trying to intensify the interaction between academia and business.

It is clear that each university operating in the region has a certain impact on the economy of the region. In general, universities have a predominantly positive impact on the local economy in the region where they operate (Rehák et al., 2015). The most important local influences of universities can be further divided into two basic categories (Strauf et al., 2008), both quantitative and qualitative. The quantitative impact is the financial impact of the universities on the region in the form of a flow of goods and money between public authorities, businesses and public institutions. The 
qualitative aspect looks more at the benefits for the economy in terms of ecological, political and socio-cultural effects.

University spin-off companies are one of the forms how the university could transform new knowledge into innovation and commercialise them. University spinoff companies are often seen as enterprises founded by university staff (or graduates) assigned to the surrounding or catchment area of that university (Strauf et al., 2008). The issue of spin-off is quite extensive and involves a wide range of elements, while university spin-off is one of the specific types of spin-off companies (Salvador, 2011). When looking at the most commonly used definitions in the literature, spin-off is generally defined as a new enterprise created to use the knowledge, technology and research results of the university and to successfully commercialize them (Wright et al., 2007).

Cusmano et al. (2014) reported that spin-offs are one of the key elements supporting regional growth. Similarly, Strauf et al. (2008) consider it essential for the region's development strategy to include knowledge transfer and innovation through project collaboration. This type of business is important, in particular, to make a connection between students and businesses (e.g. to solve specific practical problems in their thesis).

The process of creating a university spin-off is a relatively challenging one for the university. Successful transformation of knowledge into a usable product or service requires the acquisition of a number of new competences, but universities traditionally operate primarily in the non-commercial sphere (Vohora et al., 2004). To support the university's entrepreneurial competencies, it is usually crucial to create a completely new routine and leave the original educational and research based routine (Rasmussen et al., 2010). The acquisition of entrepreneurial skills may sometimes conflict with the university's traditional education and research policies (Bercovitz et al., 2008).

The success of newly created projects and spin-offs depends on a number of factors related to characteristics of each university (Bigliardi et al., 2013). Factors influencing the success of spin-off companies in selected studies (Bigliardi et al., 2013) can be summarized in the following four key points:

- university characteristics;

- characteristics of the founders of the spin-off company;

- characteristics of the surrounding environment;

- characteristics of the technology or final product itself.

In order to successfully establish the spin-off the support for these 3 critical types of competencies is needed at the university (Rasmussen et al., 2015):

- develop viable business opportunities;

- involve individuals in the business process and their subsequent active and passive support;

- providing the resources needed to set up and develop an enterprise.

The University that mostly has direct staff ties with spin-off companies, and university characteristics could have a significant positive impact on the efficiency and success of spin-off companies (Epure et al., 2014).

\section{Methodology}

In the analytical section of the paper our main aim is to identify the key differences between the university environments in selected European countries based selected indicators and further examine several factors potentially influencing the probability of an establishing university spin-off company. As a basic data source, we used the European Tertiary Education Register (2017). This database contains data available 
for 2465 higher education institutions from 36 countries in Europe. The data are available for 2011 (academic year 2011/2012), 2012 (academic year 2012/2013) and 2013 (academic year 2013/2014) and 2014 (academic year 2014/2015). We compare the average values of selected indicators in European countries and identify the key differences. With respect to the main aim of the paper, we also focused on the factors potentially influencing the creation of university spin-offs.

In the European Tertiary Education Register survey higher education institutions are supposed to indicate whether an event affecting the institution occurred in the year before or in the year following the year under review. One of these possible events is the establishment of a spin-off (or spin-out). Spin-off has to be separated from the monitored institution in selected years. Spin-out in this case means any detachment of part of a higher education institution (most often a research centre or department) and the creation of a new independent intellectual property institution or technology originating from the original institution. Based on these data we further used probit regression analysis and binary logistic regression, in order to identify potential factors affecting the establishment of the spin-off.

The variables used in regression models are further specified in Table 1.

Table 1

Description of Variables Used in Regression Models

\begin{tabular}{|c|c|}
\hline $\begin{array}{l}\text { The emergence of } \\
\text { university spin-off in the } \\
\text { period under review }\end{array}$ & $\begin{array}{c}\text { Did the university spin-off occur in the reference period } \\
\text { ?: yes (coded as 1), not (coded as } 0 \text { ) }\end{array}$ \\
\hline $\begin{array}{c}\text { Herfindahl } \\
\text { Concentration Index } \\
\text { (Specialization of } \\
\text { students) }\end{array}$ & $\begin{array}{c}\text { The index reflects the institution's degree of } \\
\text { specialization. Value } 1 \text { means that students are studying } \\
\text { in the same area, with values closer to zero meaning } \\
\text { that students are roughly evenly distributed across } \\
\text { different fields of the study. }\end{array}$ \\
\hline Intensity of PhD study & Share of PhD. students on the total number of students. \\
\hline Share of tuition fees & The share of tuition fees on total university revenue \\
\hline $\begin{array}{l}\text { Number of Erasmus } \\
\text { students }\end{array}$ & $\begin{array}{c}\text { Number of students leaving for a foreign study stay } \\
\text { through the Erasmus program }\end{array}$ \\
\hline $\begin{array}{l}\text { Share of foreign } \\
\text { students }\end{array}$ & $\begin{array}{c}\text { The share of foreign students in the total number of } \\
\text { students }\end{array}$ \\
\hline
\end{tabular}

The more precise procedure and results are mentioned in the next section of the paper.

\section{Results and Discussion}

As stated, we firstly compared selected indicators for European countries. These indicators are country averages for all higher education institution included in the sample (European Tertiary Education Register) from each country. However, selected indicators are not always available for all European countries in the sample. The countries without any valid observation have been excluded from the comparison of certain indicators. At first, we compare the Herfindahl index for PhD graduates (Figure 1) and the Herfindahl index for all ISCED students at universities (Figure 2). 
Figure 1

Herfindahl Index for PhD Graduates

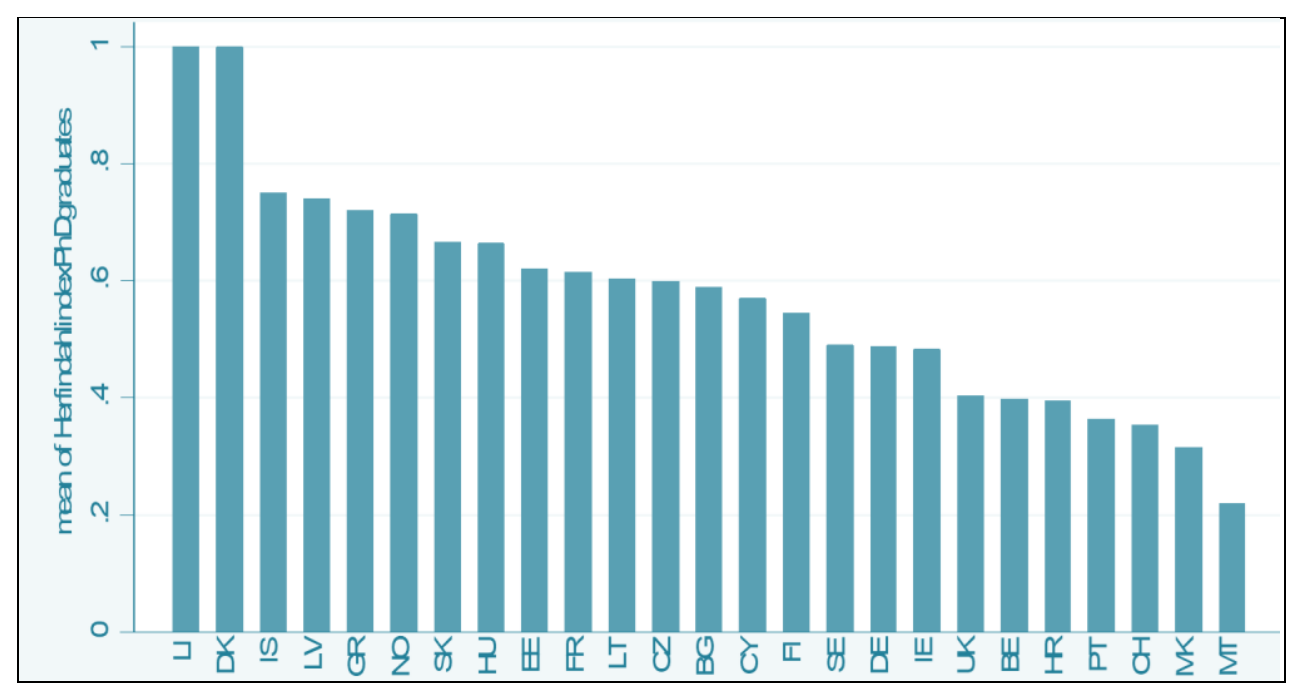

Source: Authors' work based on data from the European Tertiary Education Register (2016)

Figure 2

Herfindahl Index for all ISCED Students

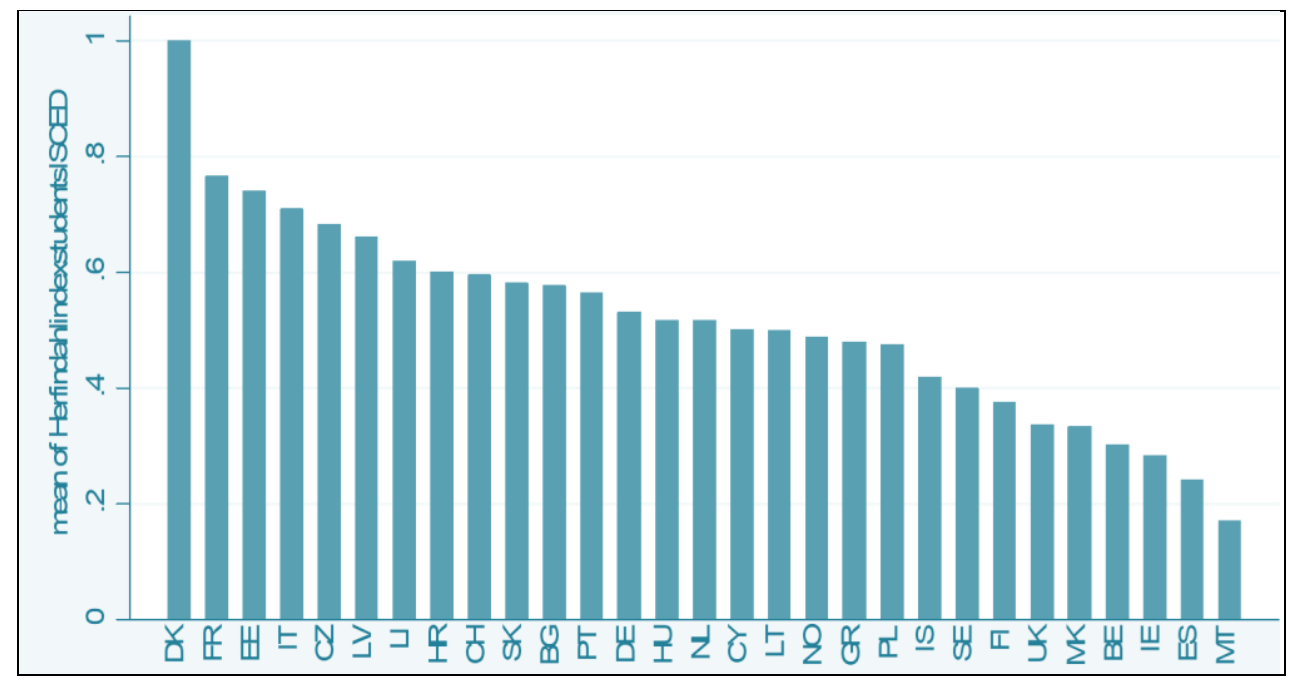

Source: Authors' work based on data from the European Tertiary Education Register (2016)

The Herfindahl index reflects the institution's degree of specialization in certain areas of study. Value 1 means that all students or graduates are studying in the same area, with values closer to zero means that students or graduates are roughly evenly distributed across different fields of study. The highest degree of specialisation of PhD study can be seen in Lichtenstein and Denmark. However in the cases of these countries only small numbers of institution have been included in the sample. On the other hand PhD. graduates form Malta, Macedonia and Switzerland are distributed more evenly across different fields of study. Furthermore, the highest values of Herfindahl index for all students are found in Demark, France and Estonia, which again suggest that students are more concentrated in certain fields of study in these countries. 
The variables in probit and logit regressions were selected based on their availability for as many institutions as possible as well as on their potential relation to spin-offs. Hence, we decided to include the Herfindhal concentration index as stated above. We also use variables related to the international orientation and international links of the institution, expressed through the share of foreign students and the number of students who went abroad through the Erasmus program. In addition, we monitor the proportion of third-degree students and the share of students' fees funding on total budget. The results of each regression are summarized in Table 2.

Table 2

Results of Logit and Probit Regression

Dependent variable: Spin-off founded in the observed period: yes (1), no (0)

\begin{tabular}{|c|c|c|c|c|}
\hline & (1) logit & (2) probit & (3) probit & $\begin{array}{l}\text { (4) } \\
\text { probit }\end{array}$ \\
\hline Herfindahl Index (PhD Study) & $\begin{array}{l}-10.78^{* * *} \\
(-4.51)\end{array}$ & $\begin{array}{l}-6.40^{* * *} \\
(-5.28)\end{array}$ & $\begin{array}{l}-7.77^{* * *} \\
(-6.59)\end{array}$ & $\begin{array}{l}-8.51^{* * *} \\
(-22.68)\end{array}$ \\
\hline Herfindahl Index (PhD Study) & $\begin{array}{l}5.29^{* *} \\
(2.44)\end{array}$ & $\begin{array}{l}3.53^{* * *} \\
(3.35)\end{array}$ & $\begin{array}{l}5.89^{* * *} \\
(5.57)\end{array}$ & $\begin{array}{l}6.09 * * * \\
(15.65)\end{array}$ \\
\hline $\begin{array}{l}\text { Herfindahl index } \\
\text { (Bachelor and Master studies) }\end{array}$ & & & $\begin{array}{l}65.81^{* * *} \\
(3.11)\end{array}$ & \\
\hline $\begin{array}{l}\text { Herfindahl index }{ }^{2} \\
\text { (Bachelor and Master studies) }\end{array}$ & & & $\begin{array}{l}-2301.3^{* * *} \\
(-4.24)\end{array}$ & \\
\hline Intensity of PhD study & $\begin{array}{l}151.63^{* * *} \\
(3.19)\end{array}$ & $\begin{array}{l}86.76^{* * *} \\
(3.35)\end{array}$ & $\begin{array}{l}65.81^{* * *} \\
(3.11)\end{array}$ & \\
\hline Intensity of PhD study ${ }^{2}$ & $\begin{array}{l}-5357.7^{* * *} \\
(-4.24)\end{array}$ & & $\begin{array}{l}-2301.3^{* * *} \\
(-4.24)\end{array}$ & \\
\hline The share of tuition fees & $\begin{array}{l}-10.87^{* * *} \\
(-2.78)\end{array}$ & $\begin{array}{l}-4.61 \\
(-4.20)\end{array}$ & $\begin{array}{l}-3.60^{* * *} \\
(-3.33)\end{array}$ & \\
\hline Number of students on Erasmus & $\begin{array}{l}0.002^{* * *} \\
(2.81)\end{array}$ & $\begin{array}{l}0.001^{* *} \\
(2.31)\end{array}$ & $\begin{array}{l}0.001^{* *} \\
(2.28)\end{array}$ & \\
\hline Share of foreign students & $\begin{array}{l}6.07^{* * *} \\
(3.53)\end{array}$ & $\begin{array}{l}3.07^{* * *} \\
(3.51)\end{array}$ & $\begin{array}{l}3.62^{* * *} \\
(3.71)\end{array}$ & \\
\hline Akaike crit. & 0.185 & 0.189 & 0.223 & 0.238 \\
\hline Log likelihood & -108.45 & -110.72 & -109.99 & -258.12 \\
\hline Number of observations & 1247 & 1247 & 1045 & 2185 \\
\hline
\end{tabular}

Source: Authors' work

The first column shows the logistic regression results (logit) and other results are based on probit regression. Both methods were used to make comparisons and validation of the results achieved. From the specialisation point of view, we used the Herfindahl concentration index for PhD study in all regressions, while in one model we also used the Herfindahl index for bachelor and master degree studies. In addition to the Herfindahl index we also applied PhD intensity indicator and its squared value to capture the potential non-linear influence.

Based on the results, spin-offs can be said to arise primarily from institutions that are either very narrow in their specialization or, on the other hand, broad-based and provide education in many areas. The creation of a spin-off company is not so common event for those higher education institutions that lie somewhere between these two extremes. This is the same for Herfindahl index of concentration at PhD. 
level as well as bachelor and master level. On the other hand, the higher the intensity of PhD. study the higher the probability of spin-off creation, but this is again valid only to certain threshold level. This means that the probability of establishing spin-off is gradually increasing along with the increasing share of PhD students up to a certain limit. Moreover, the share of foreign students as well as the number of students going abroad with institutions abroad through the Erasmus program is positively correlated with the higher probability of establishing spin-off. On the other hand, a higher proportion of tuition fees on revenues appear to be a negative factor for spin-off creation.

\section{Conclusion}

Universities are seen as a crucial institution in respect to innovation development and regional economic growth. There seem to be rather significant differences in their characteristics among different European countries. This is true for specialisation, financial resources as well as staff structure. Selected factors potentially affecting the emergence of university spin-off have been examined on the basis of data from 2465 higher education institutions from 36 European countries. The results of regression models suggest that spin-offs are typical on one hand for highly specialized universities, or on the another hand for highly-oriented universities with a wide range of study programs in different study fields. Universities that are in the middle of their specialization usually created the least number of spin-off companies. The sufficient share of doctoral students is also very important according to our results. However, there seems to be again the non-linear dependence between the share of PhD student students and the probability of creating the spin-off company. Based on the results, we believe that there is an optimal number of PhD students required to conduct research activities and consequently maximize the probability of starting the spin-off. At the same time, we have confirmed that universities with a higher proportion of foreign students are more active in setting up spin-offs. This indicator may to a certain extent reflect the scope of international cooperation and networking with foreign universities in general. Interestingly, universities that usually set up spin-off have a relatively low share of tuition income from students. Despite some methodological constraints resulting from the data used, it is possible to formulate potential implications. However, it is also necessary to state that if we assume that the establishment of spin-offs directly by universities is desirable, this should also be in line with a legislative regulation that should allow and simplify the commercialization of the results of university research. We believe that certain degree of support from national or local government should also be provided for those universities that decide to establish a spin-off. On the other hand, it is also necessary to recognize that spin-off companies are to a large extent limited to the field of technology or natural sciences. The university should also have some optimal number of doctoral candidates secured. At the same time, however, it must be said that the maximum possible number of doctoral candidates usually does not maximize the probability of establishing spin-off. From the point of view of funding, it is important for the University not to rely primarily on student fee funding, as this reduces the probability of establishing spin-off.

\section{References}

1. Bercovitz, J., Feldman, M. (2008), "Academic entrepreneurs: Organizational change at the individual level", Organization Science, Vol. 19, No. 1, pp. 69-89.

2. Bigliardi, B., Galati, F., Verbano, C. (2013), "Evaluating performance of university spinoff companies: Lessons from Italy", Journal of technology management \& innovation, 
Vol. 8, No. 2, pp. 178-188.

3. Chesbrough, H. W. (2006), Open innovation: The new imperative for creating and profiting from technology, Harvard Business Press, Boston.

4. Cusmano, L., Morrison, A., Pandolfo, E. (2014), "Spin-off and clustering: a return to the Marshallian district", Cambridge Journal of Economics, Vol 39, No. 1, pp. 49-66.

5. Dunning, J. H. (2002), Regions, Globalization and the Knowledge Economy, Oxford University Press, London.

6. Edquist, C. (2004), "Systems of Innovation: Perspectives and Challenges", in Fagerberg, J., Mowery, D., Nelson, R. (Eds). The Oxford Handbook of Innovation, Oxford University Press, Norfolk.

7. Epure, M., Prior, D., Serarols, C. (2016), "Assessing technology-based spin-offs from university support units", Regional Studies, Vol. 50, No. 3, pp. 411-428.

8. Ełzkowitz, H., Leydesdorff, L. (2000), "The dynamics of innovation: from National Systems and "Mode 2" to a Triple Helix of university-industry-government relations", Research policy, Vol. 29, No. 2, pp. 109-123.

9. European Tertiary Education Register (2017), ETER database, available at: https://www.eter-project.com/ (20 February 2018)

10. Freeman, C. (1987), "Technology policy and economic performance: Lessons from Japan", Research Policy, Vol.17, No. 5, pp. 309-310.

11. Hudec, O., Urbančíková, N., Džupka, P., Šebová, M., Klimovský, D., Suhányi, L., Želinský, T. (2009), Podoby regionálneho a miestneho rozvoja (The forms of regional and local development), Ekonomická fakulta TU, Košice.

12. Rasmussen, E., Borch, O. J. (2010), "University capabilities in facilitating entrepreneurship: A longitudinal study of spin-off ventures at mid-range universities", Research Policy, Vol. 39, No. 5, pp. 602-612.

13. Rasmussen, E., Wright, M. (2015), "How can universities facilitate academic spin-offs? An entrepreneurial competency perspective", The Journal of Technology Transfer, Vol. 40, No. 5, pp. 782-799.

14. Rehák, Š., Džupka, P., Sekelský, L., Šebová, M. (2015), Lokálne ekonomické vplyvy univerzít (Local Economic Impact of Universities), Vydavatelstvo EKONÓM, Bratislava.

15. Salvador, E. (2011), "How effective are research spin-off firms in Italy?" Revue d'économie industrielle, No. 133, pp. 99-122.

16. Sterlacchini, A. (2008), "R\&D, higher education and regional growth: Uneven linkages among European regions", Research Policy, Vol. 37, No. 6-7, pp. 1096-1 107.

17. Strauf, S., Scherer, R. (2008), "Universities and their contribution to regional development", Transformations in Business \& Economics, Vol. 7, No. 1, pp. 137-151.

18. Vohora, A., Wright, M., Lockett, A. (2004), "Critical junctures in the development of university high-tech spinout companies", Research policy, Vol. 33, No. 1, pp. 147-175.

19. Wright, M., Clarysse, B., Mustar, P., Lockett, A. (2007), Academic Entrepreneurship in Europe, Edward Elgar, Cheltenham. 


\section{About the authors}

Jan Hunady, PhD. is assistant professor at the Faculty of Economics, Matej Bel University in Banska Bystrica, Slovakia. He received his PhD in public economics and services at Matej Bel Univeristy. He has already published a number of papers at conferences and journals, primarily in the area of public finance and innovation. He also participates on several research projects in the area of research policy and innovation. He has expertise in econometrics and econometrics package programs particularly panel data and time series analysis. The author can be contacted at jan.hunady@umb.sk.

prof. Ing. Marta Orviska, PhD. is professor of finance, banking and investment at Matej Bel University. She is one of the most cited economists in Slovakia. Her research interests are focused on macroeconomics and public finance, including tax policy and tax evasion, standardisation, voting behaviour and the analysis of attitudes to, for example, NATO and the EU in the new applicant countries and new members of the EU, and to new technologies. Since 2000, she has held and hold several positions in national and international projects in these areas and she has published a number of articles including in the European Journal of Political Economy, Journal of Common Market Studies, Social Indicators Research, Economics of Governance, Journal of Policy Modelling, Information Economics and Policy, Central European Journal of Public Policy, South East European Journal of Economics and Business, Politicka ekonomie, Drug Discovery Today and Nano Today. The author can be contacted at marta.orviska@umb.sk.

doc. Ing. Peter Pisar, PhD. is associate professor of finance, banking and investment at Matej Bel University. He has been the Head of Department of Finance and Accounting since 2015 executive editor of the scientific journal Region Direct and project manager of Europe Direct Information Center Relay, European Commission, Brussels, REIC Banska Bystrica, Slovakia. His research is focused on European public finances, especially innovative financing and the evaluation of regional policy and public expenditure programs. In practice, he is also a consultant for the development and implementation of projects supported by EU funds and is particularly concerned with public policies supporting innovation. The author can be contacted at peter.pisar@umb.sk. 